\title{
Variable absorption of mutational trends by prion-forming domains during Saccharomycetes evolution
}

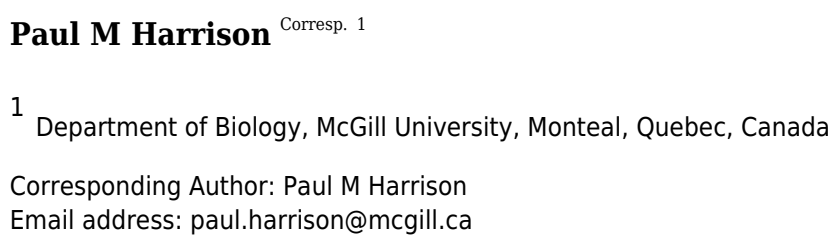

Prions are self-propagating alternative states of protein domains. They are linked to both diseases and functional protein roles in eukaryotes. Prion-forming domains in Saccharomyces cerevisiae are typically domains with high intrinsic protein disorder (i.e., that remain unfolded in the cell during at least some part of their functioning), that are converted to self-replicating amyloid forms. $S$. cerevisiae is a member of the fungal class Saccharomycetes, during the evolution of which a large population of prion-like domains has appeared. It is still unclear what principles might govern the molecular evolution of prion-forming domains, and intrinsically disordered domains generally. Here, it is discovered that in a set of such prion-forming domains some evolve in the fungal class Saccharomycetes in such a way as to absorb general mutation biases across millions of years, whereas others do not, indicating a spectrum of selection pressures on composition and sequence. Thus, if the bias-absorbing prion formers are conserving a prion-forming capability, then this capability is not interfered with by the absorption of bias changes over the duraton of evolutionary epochs. Evidence is discovered for selective constraint against the occurrence of lysine residues (which likely disrupt prion formation) in S. cerevisiae prion-forming domains as they evolve across Saccharomycetes. These results provide a case study of the absorption of mutational trends by compositionally biased domains, and suggest methodology for assessing selection pressures on the composition of intrinsically disordered regions. 
2 Variable absorption of mutational trends by prion-forming domains

3 during Saccharomycetes evolution

4

5

6 Department of Biology,

7 McGill University,

8 Montreal, QC,

9 Canada.

10

11 Corresponding author:

12 Paul Harrison

13 Email: paul.harrison@mcgill.ca

14

15

16 
17

18

19

20

21

22

23

24

25

26

27

Abstract:

8

Prions are self-propagating alternative states of protein domains. They are linked to both diseases and functional protein roles in eukaryotes. Prion-forming domains in Saccharomyces cerevisiae are typically domains with high intrinsic protein disorder (i.e., that remain unfolded in the cell during at least some part of their functioning), that are converted to self-replicating amyloid forms. S. cerevisiae is a member of the fungal class Saccharomycetes, during the evolution of which a large population of prion-like domains has appeared. It is still unclear what principles might govern the molecular evolution of prion-forming domains, and intrinsically disordered domains generally. Here, it is discovered that in a set of such prion-forming domains some evolve in the fungal class Saccharomycetes in such a way as to absorb general mutation biases across millions of years, whereas others do not, indicating a spectrum of selection pressures on composition and sequence. Thus, if the bias-absorbing prion formers are conserving a prionforming capability, then this capability is not interfered with by the absorption of bias changes over the duraton of evolutionary epochs. Evidence is discovered for selective constraint against the occurrence of lysine residues (which likely disrupt prion formation) in S. cerevisiae prionforming domains as they evolve across Saccharomycetes. These results provide a case study of the absorption of mutational trends by compositionally biased domains, and suggest methodology for assessing selection pressures on the composition of intrinsically disordered regions.

\section{Introduction}

Prion formation and propagation has been discovered and investigated chiefly in the budding yeast Saccharomyces cerevisiae, which is a member of the fungal class Saccharomycetes. The yeast $S$. cerevisiae has $>200$ prion-like proteins that have N/Q-rich domains of the sort 
40 observed in $\geq 8$ known prion-formers (An et al. 2016) (Harbi \& Harrison 2014a; Harbi et al. 2012).

41 Such yeast prions have been causally associated with diverse phenomena including evolutionary 42 capacitance, large-scale genetic control, and yeast disease-like conditions. Examples of these 43 proteins in S. cerevisiae are reviewed in the Introduction to a previous paper (Su \& Harrison 2019). 44 In the fission yeast Schizosaccharomyces pombe and the fungus Podospora anserina, there are 45 also observed prions (Saupe 2011; Sideri et al. 2017). Recently, prion-like proteins have been 46 associated with the formation of membraneless biomolecular condensates, such as stress granules 47 (Franzmann et al. 2018; Jain et al. 2016).

A bias for the polar residues asparagine $(\mathrm{N})$ and/or glutamine $(\mathrm{Q})$, and high intrinsic disorder are major features of the amyloid-based prion formers (Harbi \& Harrison 2014b). Computer programs that discriminate prion-like sequence compositions have been derived for annotating potential prion-forming regions (Alberti et al. 2009; Espinosa Angarica et al. 2013; Lancaster et al. 2014; Ross et al. 2013; Zambrano et al. 2015). deeply since in early chordates a Prion Protein ancestral gene appeared (Ehsani et al. 2011; Harrison et al. 2010; Westaway et al. 2011). However, Sup35p (which underlies the $\left[\mathrm{PSI}^{+}\right]$prion) has an N/Q bias that is prevalent across the Ascomycota and Basidiomycota phyla, which had a

57 last common ancestor $>1$ billion years ago (Harrison et al. 2007). A surge in the emergence of 58 N/Q-rich yeast-prion-like proteins early in Saccharomycetes evolution resulted from mutational trends to form more polyasparagine tracts, providing the molecular basis from which several known prion-forming domains seem to have spawned (An et al. 2016). Prion-forming domains

61 from $S$. cerevisiae tend to evolve more quickly as sequences than other prion-like domains but 62 maintain their prion-like composition ( $\mathrm{Su} \&$ Harrison 2019). In humans, several yeast-prion-like 
63 proteins are implicated in neurodegenerative processes (Kim et al. 2013; Pokrishevsky et al.

64 2016; Sun et al. 2011). In Aplysia and Drosophila, such proteins have been associated with

65 formation and preservation of long-term memory (Khan et al. 2015; Si et al. 2010). Other 66 eukaryotes, such as Drosophila melanogaster, Plasmodium falciparum and the leech Helobdella

67 robusta are home to substantial sets of prion-like proteins (An \& Harrison 2016; Pallares et al.

68 2018). The slime mold Dictyostelium has greater than fifth of its proteome displaying prion-like

69 composition (An \& Harrison 2016; Malinovska et al. 2015), and it maintains a cellular system for

70 avoiding prion-like aggregation and propagation (Malinovska \& Alberti 2015; Malinovska et

71 al. 2015). In all domains of life, prion-like proteins have been observed (Espinosa Angarica et

72 al. 2013)(Tetz \& Tetz 2017; Tetz \& Tetz 2018), with many thousands annotated in bacteria

73 (Harrison 2019; Iglesias et al. 2015). Bacterial prion-forming proteins have been observed

74 experimentally (Molina-Garcia et al. 2018; Shahnawaz et al. 2017; Yuan et al. 2014; Yuan \&

75 Hochschild 2017). Hundreds of bacterial prion-like proteins occur across multiple bacterial phyla 76 in a sparse conservation pattern (Harrison 2019).

77 Here, the evolution of the sequences of prion-forming domains in Saccharomycetes is re-

78 visited, but from the point of view of mutation biases. Protein regions are discovered to variably

79 absorb mutation biases that are observable in the proteome as a whole. This is evidenced in the

80 numbers of prion-like proteins, the percentage of guanidine and cytidine $(\mathrm{GC} \%)$ in the DNA, and

81 the proportions of poly-asparagine and poly-glutamine.

82

83 Methods

84 Data 
87 forming domains (Data S1) and their orthologs across Saccharomycetes were collated as 88 previously described (Su \& Harrison 2019).

89

Prion-like composition

Prion-like composition in orthologs was calculated in two ways, firstly using the PLAAC

92 prion-like domain annotation program (Lancaster et al. 2014), and secondly using the fLPS

93 program for annotation of compositional biases (Harrison 2017). These were both run using default parameters, except that for fLPS the expected frequency for glutamine and asparagine residues was set equal to 0.05 . For PLAAC, both the PRD score and the LLR score were analysed; the former is an indicator of the overall amount of prion-like composition in an annotated bounded

97 prion-like region, while the latter indicates the prion-like sequence composition of the best sequence window (Lancaster et al. 2014). PLAAC scores $<0.0$ or labelled ' $N / A$ ' in the output are

99 set equal to 0.0 here.

\section{Measures of proteome bias}

102 Several measures of compositional bias across proteomes/genomes were examined:

(i) $\% \mathrm{~N}($ asparagine) in the proteome;

$104 \quad$ (ii) $\% \mathrm{Q}$ (glutamine) in the proteome;

105 (iii) $\%$ poly-N in the proteome (with a minimum tract length of 3 );

106 (iv) $\%$ poly-Q in the proteome (with a minimum tract length of 3);

107 (v) $\%$ poly- $\mathrm{Q}+$ poly- $\mathrm{N}$ in the proteome (with a minimum tract length of 3 ); 
(vi) $\% \mathrm{GC}$ in the DNA;

109

110

111

112

113

114

115

116

117

118

119 120

121

122

123

124

125

126

127

128

129

130

(vii) The fraction of N/Q-rich proteins in the proteome according to a specific fLPS bias Pvalue threshold (either 1e-08, 1e-10 or 1e-12);

(viii) The fraction of proteins in the proteome with prion-like composition according to the program PLAAC (with PRD score $>0.0, \geq 15.0$ or $\geq 30.0$, or similarly for LLR score).

Measures (i) to (v) were chosen since there are indicative of general mutational trends that are relevant to the predominant compositional biases of prion-forming domains in S. cerevisiae, namely bias towards asparagine and glutamine and tracts of these residue types (An et al. 2016). Measure (vi) (\%GC) is the most basic compositional trend that can be analyzed for genomic DNA, which might underlie trends at the amino-acid level. Measures (vii) to (viii) indicate the degree to which individual proteins throughout the proteome have prion-like compositional biases to a certain level, and so would indicate how every protein is on average affected by mutational trends.

\section{Correlations}

Both weighted and unweighted Pearson correlation coefficients were calculated to assess the correlations of individual prion-like composition with the general trends in the proteome. Weightings for plot points were calculated according to their closest similarity with another protein, calculated as $(1-\% \mathbf{I} / 100)$, where $\% \mathbf{I}$ is the percentage sequence identity in the most significant BLASTP sequence alignment (Altschul et al. 1997). These weightings were summed appropriately, as described in previous analyses (Harrison 2019; Su \& Harrison 2019). Results indicate that the overall outcomes for specific proteins are not affected by non-usage of such weightings (see below). 


\section{Results}

132 Initial example: the Ure2 prion-forming domain demonstrates strong absorption of mutational 133 trends

As an initial example, the evolutionary behaviour of compositional biases in the prionforming domain of Ure2p, which underlies the [URE3] prion, was examined (Figures 1-2). The current data indicate that an ancestor of the Ure2p prion-forming domain with a strong N/Q-rich prion-like composition originated early in Saccharomycetes evolution (at least in the last common ancestor of the diverse families Debaryomycetaceae and Saccharomycetaceae), in agreement with results in previous publications (An et al. 2016; Harrison et al. 2007) (Figure 3; the organismal branching pattern from recent fungal phylogenies was used (Kurtzman \& Robnett 2013; Shen et

141 al. 2016)). In general, there is a strong correlation between the degree of bias in the N/Q-rich region

142 of Ure $2 p$ and the degree of compositional bias in the whole proteome/genome by several indicators

143 (\%polyasparagine or \%[polyasparagine + polyglutamine] or DNA GC\% or fraction of N/Q-rich

144 prion-like proteins with fLPS P-value $<10^{-10}$ ) (Figure 1). The correlations with PLAAC prion-like

145 composition score are lower, but both measures have strong correlations with \%GC in DNA

146 (Figure 2). Thus, during the surge in formation of prion-like regions during Saccharomycetes

147 evolution (An et al. 2016), the degree of N-bias in the individual prion-former Ure2p also increased 148 in correlation with the general trend as it panned out across various sub-clades.

Other prion-forming proteins show a variable spectrum of absorption of mutational trends across Saccharomycetes 
$15484 \%$ of orthologs for Cyc8p, 98\% for Swilp, and 90\% for Sup35p; Table S1), with such domains

155 of these latter three also arising in other Ascomycota clades (An et al. 2016; Harrison et al. 2007).

156 In general, there are strong correlations for Ure2p, Swip and Cyc8p with \%N, \%poly-N, \%GC in

157 DNA and with the numbers of proteins with prion-like composition (Tables 1-2). Within these

158 general trends, these four demonstrate a spectrum of responses to the overall proteome-wide

159 mutational trends, with Ure $2 p$ being the strongest correlator. Sup35p stands out as an exception; it

160 shows on the whole weaker correlations generally with $\% \mathrm{~N}$ and $\%$ poly- $\mathrm{N}$, and stronger

161 correlations with \%poly-Q than the other three. This may be because there is selection pressure to

162 maintain a specific proportion of Qs in specific local patterns or ratios (MacLea et al. 2015).

163 Furthermore, Pin3 protein also has a widespread prion-like domain across

164 Saccharomycetes, there being 52/55 (95\%) Saccharomycetes Pin3 orthologs having PLAAC LLR

165 scores $>15.0$. However, the degree of conservation of N/Q-rich bias per se is lower for this protein

166 with 38/55 (75\%) having a fLPS compositional bias P-value $\leq 1 \mathrm{e}-10$. The metastable prion domain

167 of Pin3 is the only known amyloid-based prion in S. cerevisiae to demonstrate very little

168 correlation for its prion-like compositional biases, indicating some selection pressure for

169 composition of a different sort, that nonetheless may preserve prion-forming ability (Tables 1-2).

170 The other three cases (Mot3p, Rnq1p and Nup100p) have either more recent ancestry as

171 novel prion-like domains within Saccharomycetes (in the case of Mot3p and Rnq1p), or they arise

172 sporadically in fungal species (Nup100p) (An et al. 2016; Su \& Harrison 2019). These three are

173 thus not expected to demonstrate many significant correlations with measures of compositional

174 bias, but nonetheless we see a mild negative correlation for the fLPS compositional bias of Rnq1p

175 and Mot3p versus \%Q in the proteome (Table 1), which is not typical of the other prion-forming 
176 proteins, suggesting selection pressures against Q bias in these evolutionarily recently emergent 177 proteins.

178 There is one species that is often a far outlier when these trends are examined, Ascoidea 179 rubescens (see for example, for Ure2p in Figures 1-2), an uncharacterized species that is the sole 180 member of the family Ascoideaceae, which is geographically widely distributed and typically 181 grows in beetle galleries in dead wood. It has a very high proportion of poly-N-rich proteins 182 (Tables 1-2). Removal of this outlier species from the correlation analysis causes a substantial 183 increase in correlations with $\% \mathrm{~N}$ and $\%$ poly-N, but not for $\% \mathrm{GC}$ in DNA.

184 Thus, the three S. cerevisiae prion-forming proteomes Ure2p, Cyc8p and Swilp appear to 185 absorb the general mutational trends linked to the surge in formation of prion-like domains, that 186 was observed previously (An et al. 2016). This trend is linked to a general decrease in \%GC in the 187 DNA (Tables 1-2).

188 Two other separately studied prion-forming domains are from New1p and Pub1p (Li et al. 189 2014; Osherovich \& Weissman 2001). These are both strongly correlated proteome-bias absorbers, 190 with Publp (which is a hub for protein interaction with other prion-like proteins (Harbi \& Harrison 191 2014b)) uniquely amongst all of the prion-forming domains displaying a strong correlation for

192 both poly-N and poly-Q (Tables 1-2). Publp is strongly correlated despite having a low number 193 of orthologous prion domains that have high bias for $\mathrm{N}$ and Q residues (53\% with fLPS P-value $194 \leq 1 \mathrm{e}-10$; Table S1) indicating that there is still correlated behavior for the weaker N/Q biases for 195 this protein. Other prion-forming domains observed in the analysis of Alberti, et al. (Alberti et al. 196 2009), also display a similar spectrum of bias absorption across Saccharomycetes evolution (Table 197 S2). Highly-correlated bias absorbers from this data whose prion-like domains are widespread in 
198 Saccharomycetes include Lsm4p and Gln3p, whereas other widespread prion-like domains show

199 little or no correlation, such as Ngr1p (Tables S1, S2).

200 Compared to the results for N/Q-compositional bias calculated using fLPS (Table 1), the

201 trends for prion-like composition calculated using the PRDscore from PLAAC, are similar except

202 that New1p loses many significant correlations, and an increased correlation is captured for

203 Sup35p versus the general mutational trends linked to the large-scale surge in formation of prion-

204 like domains (An et al. 2016). Similar trends for PLAAC are observed if Spearman correlation

205 coefficients are applied (by reason of some proteins having several 0.0-value PLAAC PRDscores

206 in orthologs) (Table S3).

207 The above analysis uses the PLAAC PRDscore, to define the amount of prion-like 208 composition in a bounded region, and so reflecting more absorption of biases in a way analogous 209 to the working of the fLPS algorithm (Harrison 2017; Lancaster et al. 2014). The PLAAC log210 likelihood ratio (LLR) score has been used in the literature to pick out the most likely prion-

211 forming sequence window within proteins (Alberti et al. 2009; An et al. 2016; Sideri et al. 2017;

212 Tetz \& Tetz 2018). Despite the restriction of a window of fixed size (41 amino-acid residues),

213 these LLR scores also demonstrate a similar spectrum of bias absorption, with both strong and 214 weak absorbers evident, albeit generally with less significance (Table S4).

Prion-like N/Q-rich regions generally maintain lower lysine content than the rest of the

\section{7 proteome in Saccharomycetes}

218 It was checked whether the N/Q-rich regions are also rich in lysine, which is encoded by

219 AT\%-rich codons, like N (asparagine). Lysine has low prion formation propensity and charged

220 residues are disruptive to prion formation and have low prion formation propensity (Lancaster et 
221 al. 2014; Osherovich \& Weissman 2001). Lysine is a disorder-promoting residue (Oldfield \&

222 Dunker 2014) and some intrinsically disordered regions have high positive charge (Hatos et al.

223 2020; Necci et al. 2018). However, the N/Q-rich regions consistently in general have lower lysine

224 content that the remainder of the Saccharomycetes proteomes (Figure 4). That is, the vast majority

225 of Saccharomycetes species ( $\sim 98 \%)$ are below the $x=y$ line on the scatter plot (Figure $4 \mathrm{~A})$. This is

226 also obvious in the distributions of $\mathrm{K}$ fraction (Figure 4B, values for prion-formers are lower, $t$ -

227 test $\mathrm{P}=1 \mathrm{e}-140$ ). Thus, these regions are not simply absorbing higher levels of AT\% in their DNA

228 through the embedding within them of amino-acid residues encoded by codons with high AT\%.

229

230 Discussion

231 These results indicate that compositional aspects of many individual prion-formers

232 behaved in a correlated way in relation to general trends as they panned out over millions of years

233 across various sub-clades. Also, this surge in prion-like region formation is directly linked to a

234 general trend for GC\% decrease across the Saccharomycetes clade. However, some prion-forming

235 domains resist the absorption of such mutational trends, such as the meta-stable prion-former

236 Lsb2/Pin3 (Chernova et al. 2017b), despite it being as widely conserved as a protein as those that

237 more easily absorb biases, such as Cyc8p and Swilp. This suggests some greater selection pressure

238 on amino-acid composition. The Sup35p prion-forming domain also shows some special behavior:

239 demonstrating a stronger correlation between overall proteome poly-Q levels and its own N or Q

240 compositional bias as determined by the program fLPS. The Sup35 prion-forming domain has a

241 subdomain with specific local patterns involving Q residues that is required for chaperone-

242 dependent prion maintenance, that is separate from the N-terminal N/Q-rich region that is

243 necessary for prion nucleation and fibre growth (MacLea et al. 2015). Also, the Sup35 prion-like 
244 domain has a more ancient origin before the last common ancestor of Saccharomycetes, and

245 outside this clade it tends to have a predominant Q-bias that has been maintained within

246 Saccharomycetes, resisting the trend for greater N-bias (An et al. 2016). However, this is also the

247 behaviour of Cyc8p and Swilp outside of Saccharomycetes (An et al. 2016), so this result is 248 demonstrating an evolutionary behavior peculiar to Sup35p.

249 The Publp prion-forming domain shows strong correlations for both $\mathrm{Q}$ and $\mathrm{N}$ bias 250 indicators. It is possible that proteins such as Pub1p that interact a lot with other prion-like proteins 251 (Harbi \& Harrison 2014b) 'need' to absorb more general compositional trends so that they can 252 promiscuously bind with a large list of partners. Prion-like aggregation has been shown for both 253 Pub1p in yeast and for its co-ortholog Tial in humans (Gilks et al. 2004; Li et al. 2014). Its prion254 like composition has also largely been maintained since the last common ancestor of eukaryotes 255 (Su \& Harrison 2020). Thus, its strong absorption of mutational trends for Q and $\mathrm{N}$ residues has 256 not been a barrier to such a conservation of prion-like composition. The methodology applied here might also be useful in the analysis of human proteins with 258 N/Q biases, such as those linked to amytrophic lateral sclerosis or huntingtin from Huntington's 259 disease (An \& Harrison 2016; Monahan et al. 2018), or to other non-N/Q-biased prion-forming 260 domains, such as in alpha-synuclein (Watts 2019). In particular, prion-forming domains from any 261 such proteins that display little or no correlation with general compositional trends in the proteome 262 may be under selection pressure against aggregation, or for a functional role for which 263 compositional sequence parameters are precisely modulated. Recent research suggests that 264 sequence mutations leading to subtle amino-acid side-chain differences in a short disordered 265 segment of the Sup35p prion-forming domain alter its conformational preferences and markedly 266 modify its cross-reactivity with infectious prion seeds (Shida et al. 2020). Such subtle effects are 
267 interesting in light of the fact that prion formation is largely governed by compositional

268 preferences (Cascarina et al. 2018; Ross et al. 2004; Toombs et al. 2010). Given such

269 considerations, our results imply that some specific segments of prion-forming domains may be

270 under selective constraint, while other segments are more free to absorb large-scale mutational

271 trends, such as the surge in asparagine-rich prion-like tracts during Saccharomycetes speciation

272 (An \& Harrison 2016).

273 One form of selective constraint was examined in detail, the avoidance of lysine residues.

274 Both asparagine and lysine are encoded by an AT-rich codon repertoire that just differs at the third

275 codon position. Naively one would expect them to co-occur, since lysine has disorder-promoting

276 character and prion-forming domains are intrinsically disordered (Harbi \& Harrison 2014a; Harbi

277 et al. 2012). However, lysine has low prion formation propensity and charged residues are

278 disruptive to prion formation and have low prion formation propensity (Lancaster et al. 2014;

279 Osherovich \& Weissman 2001). Here, we observed that lysine residues are avoided as S. cerevisiae

280 prion-forming domains evolve across Saccharomycetes. Further development of such co-

281 occurrence analysis for amino-acid residue types might yield further clues about the conservation

282 of prion-forming status or other selective constraints on amino-acid composition in protein regions

283 of unknown character (Harrison 2018).

284 The results here provide a case study of mutational trend absorption by disordered regions

285 generally. The results suggest some methodology for analyzing selection pressures on individual

286 intrinsically disordered regions within the context of the behaviour of other sequences from the 287 same proteome.

289 Conclusions 
291 continually absorbing overall mutational trends in their proteomes, but this is modulated by

292 specific selection pressures. A spectrum of bias absorption is observed from Lsb2/Pin3---which

293 appears refractive to the mutational trends and shows little or no correlation---to Pub1, which

294 shows very strong correlation to both asparagine- and glutamine-based biases.

295 The present analysis can be seen as a case study of the absorption of mutational trends in 296 compositionally biased domains. The $S$. cerevisiae prion-forming list of proteins is particularly

297 well-suited for this. Firstly, there is a substantial set of them that has accumulated via experimental

298 analysis over the past two decades. Secondly, within the Saccharomycetes there has been a

299 wholesale shift in mutational trends relative to other fungi over the past hundreds or millions of

300 years, which provides the major context for their molecular evolution. This work can be expanded 301 to analyze further these phenomena on a larger scale.

\section{References}

304 Alberti S, Halfmann R, King O, Kapila A, and Lindquist S. 2009. A systematic survey identifies prions and illuminates sequence features of prionogenic proteins. Cell 137:146-158.

Altschul SF, Madden TL, Schaffer AA, Zhang J, Zhang Z, Miller W, and Lipman DJ. 1997. Gapped BLAST and PSI-BLAST: a new generation of protein database search programs. Nucleic Acids Res 25:3389-3402.

An L, Fitzpatrick D, and Harrison PM. 2016. Emergence and evolution of yeast prion and prionlike proteins. BMC Evol Biol 16:24. 10.1186/s12862-016-0594-3

311 An L, and Harrison PM. 2016. The evolutionary scope and neurological disease linkage of yeastprion-like proteins in humans. Biol Direct 11:32. 10.1186/s13062-016-0134-5 
313 Boeckmann B, Bairoch A, Apweiler R, Blatter MC, Estreicher A, Gasteiger E, Martin MJ,

314 Michoud K, O'Donovan C, Phan I, Pilbout S, and Schneider M. 2003. The SWISS-PROT

315 protein knowledgebase and its supplement TrEMBL in 2003. Nucleic Acids Res 31:365-

$316 \quad 370$.

317 Cascarina SM, Paul KR, Machihara S, and Ross ED. 2018. Sequence features governing

318 aggregation or degradation of prion-like proteins. PLoS Genet 14:e1007517.

$319 \quad$ 10.1371/journal.pgen.1007517

320 Chernova TA, Chernoff YO, and Wilkinson KD. 2017a. Prion-based memory of heat stress in

$321 \quad$ yeast. Prion 11:151-161. 10.1080/19336896.2017.1328342

322 Chernova TA, Kiktev DA, Romanyuk AV, Shanks JR, Laur O, Ali M, Ghosh A, Kim D, Yang

Z, Mang M, Chernoff YO, and Wilkinson KD. 2017b. Yeast Short-Lived Actin-

324

325 Associated Protein Forms a Metastable Prion in Response to Thermal Stress. Cell Rep

326 18:751-761. 10.1016/j.celrep.2016.12.082

Cox B. 1965. [PSI], a cytoplasmic suppressor of super-suppression in yeast. Heredity 20:505521.

Ehsani S, Tao R, Pocanschi CL, Ren H, Harrison PM, and Schmitt-Ulms G. 2011. Evidence for retrogene origins of the prion gene family. PLoS One 6:e26800. 10.1371/journal.pone.0026800

331 Espinosa Angarica V, Ventura S, and Sancho J. 2013. Discovering putative prion sequences in complete proteomes using probabilistic representations of $\mathrm{Q} / \mathrm{N}$-rich domains. $B M C$ Genomics 14:316. 10.1186/1471-2164-14-316 
334 Franzmann TM, Jahnel M, Pozniakovsky A, Mahamid J, Holehouse AS, Nuske E, Richter D,

335 Baumeister W, Grill SW, Pappu RV, Hyman AA, and Alberti S. 2018. Phase separation

336 of a yeast prion protein promotes cellular fitness. Science $359.10 .1126 /$ science.aao5654

337 Gilks N, Kedersha N, Ayodele M, Shen L, Stoecklin G, Dember LM, and Anderson P. 2004.

338 Stress granule assembly is mediated by prion-like aggregation of TIA-1. Mol Biol Cell

$339 \quad 15: 5383-5398.10 .1091 /$ mbc.e04-08-0715

340 Harbi D, and Harrison PM. 2014a. Classifying prion and prion-like phenomena. Prion 8.

341 Harbi D, and Harrison PM. 2014b. Interaction networks of prion, prionogenic and prion-like

342 proteins in budding yeast, and their role in gene regulation. PLoS One 9:e100615.

$343 \quad$ 10.1371/journal.pone.0100615

344 Harbi D, Parthiban M, Gendoo DM, Ehsani S, Kumar M, Schmitt-Ulms G, Sowdhamini R, and 345 Harrison PM. 2012. PrionHome: a database of prions and other sequences relevant to $346 \quad$ prion phenomena. PLoS One 7:e31785.

347 Harrison LB, Yu Z, Stajich JE, Dietrich FS, and Harrison PM. 2007. Evolution of budding yeast 348 prion-determinant sequences across diverse fungi. J Mol Biol 368:273-282.

349 Harrison PM. 2017. fLPS: Fast discovery of compositional biases for the protein universe. $B M C$ 350 Bioinformatics 18:476. 10.1186/s12859-017-1906-3

351 Harrison PM. 2018. Compositionally biased dark matter in the protein universe. Proteomics:e1800069. 10.1002/pmic.201800069

353 Harrison PM. 2019. Evolutionary behaviour of bacterial prion-like proteins. PLoS One 354 14:e0213030. 10.1371/journal.pone.0213030 
355 Harrison PM, Khachane A, and Kumar M. 2010. Genomic assessment of the evolution of the 356 prion protein gene family in vertebrates. Genomics 95:268-277.

357

358

359

360

361

362

363

364

365

366

367

368

369

370

371

372

373

374

375 10.1016/j.ygeno.2010.02.008

Hatos A, Hajdu-Soltesz B, Monzon AM, Palopoli N, Alvarez L, Aykac-Fas B, Bassot C, Benitez GI, Bevilacqua M, Chasapi A, Chemes L, Davey NE, Davidovic R, Dunker AK, Elofsson A, Gobeill J, Foutel NSG, Sudha G, Guharoy M, Horvath T, Iglesias V, Kajava AV, Kovacs OP, Lamb J, Lambrughi M, Lazar T, Leclercq JY, Leonardi E, Macedo-Ribeiro S, Macossay-Castillo M, Maiani E, Manso JA, Marino-Buslje C, Martinez-Perez E, Meszaros B, Micetic I, Minervini G, Murvai N, Necci M, Ouzounis CA, Pajkos M, Paladin L, Pancsa R, Papaleo E, Parisi G, Pasche E, Barbosa Pereira PJ, Promponas VJ, Pujols J, Quaglia F, Ruch P, Salvatore M, Schad E, Szabo B, Szaniszlo T, Tamana S, Tantos A, Veljkovic N, Ventura S, Vranken W, Dosztanyi Z, Tompa P, Tosatto SCE, and Piovesan D. 2020. DisProt: intrinsic protein disorder annotation in 2020. Nucleic Acids Res 48:D269-D276. 10.1093/nar/gkz975

Holmes DL, Lancaster AK, Lindquist S, and Halfmann R. 2013. Heritable remodeling of yeast multicellularity by an environmentally responsive prion. Cell 153:153-165.

Iglesias V, de Groot NS, and Ventura S. 2015. Computational analysis of candidate prion-like proteins in bacteria and their role. Front Microbiol 6:1123. 10.3389/fmicb.2015.01123

Jain S, Wheeler JR, Walters RW, Agrawal A, Barsic A, and Parker R. 2016. ATPase-Modulated Stress Granules Contain a Diverse Proteome and Substructure. Cell 164:487-498. 10.1016/j.cell.2015.12.038 
376 Khan MR, Li L, Perez-Sanchez C, Saraf A, Florens L, Slaughter BD, Unruh JR, and Si K. 2015.

377 Amyloidogenic Oligomerization Transforms Drosophila Orb2 from a Translation

378 Repressor to an Activator. Cell 163:1468-1483. 10.1016/j.cell.2015.11.020

379 Kim HJ, Kim NC, Wang YD, Scarborough EA, Moore J, Diaz Z, MacLea KS, Freibaum B, Li S, 380 Molliex A, Kanagaraj AP, Carter R, Boylan KB, Wojtas AM, Rademakers R, Pinkus JL, 381 Greenberg SA, Trojanowski JQ, Traynor BJ, Smith BN, Topp S, Gkazi AS, Miller J, 382 Shaw CE, Kottlors M, Kirschner J, Pestronk A, Li YR, Ford AF, Gitler AD, Benatar M,

Kurtzman CP, and Robnett CJ. 2013. Relationships among genera of the Saccharomycotina King OD, Kimonis VE, Ross ED, Weihl CC, Shorter J, and Taylor JP. 2013. Mutations in prion-like domains in hnRNPA2B1 and hnRNPA1 cause multisystem proteinopathy and

Lacroute F. 1971. Non-Mendelian mutation allowing ureidosuccinic acid uptake in yeast. $J$ Bacteriol 106:519-522.

391 Lancaster AK, Nutter-Upham A, Lindquist S, and King OD. 2014. PLAAC: a web and command-line application to identify proteins with prion-like amino acid composition. Bioinformatics 30:2501-2502. 10.1093/bioinformatics/btu310 prion domains: directing protein synthesis machinery to the tubulin cytoskeleton. Mol Cell 55:305-318. 10.1016/j.molcel.2014.05.027 
397 MacLea KS, Paul KR, Ben-Musa Z, Waechter A, Shattuck JE, Gruca M, and Ross ED. 2015.

398 Distinct amino acid compositional requirements for formation and maintenance of the $399 \quad[\mathrm{PSI}(+)]$ prion in yeast. Mol Cell Biol 35:899-911. 10.1128/MCB.01020-14

400 Malinovska L, and Alberti S. 2015. Protein misfolding in Dictyostelium: Using a freak of nature 401 to gain insight into a universal problem. Prion 9:339-346.

402 $10.1080 / 19336896.2015 .1099799$

403 Malinovska L, Palm S, Gibson K, Verbavatz JM, and Alberti S. 2015. Dictyostelium discoideum 404 has a highly Q/N-rich proteome and shows an unusual resilience to protein aggregation. $405 \quad$ Proc Natl Acad Sci U S A 112:E2620-2629. 10.1073/pnas.1504459112

McGlinchey RP, Kryndushkin D, and Wickner RB. 2011. Suicidal [PSI+] is a lethal yeast prion. Proc Natl Acad Sci U S A 108:5337-5341.

Molina-Garcia L, Gasset-Rosa F, Alamo MM, de la Espina SM, and Giraldo R. 2018. Addressing Intracellular Amyloidosis in Bacteria with RepA-WH1, a Prion-Like Protein. Methods Mol Biol 1779:289-312. 10.1007/978-1-4939-7816-8_18

Monahan ZT, Rhoads SN, Yee DS, and Shewmaker FP. 2018. Yeast Models of Prion-Like Proteins That Cause Amyotrophic Lateral Sclerosis Reveal Pathogenic Mechanisms.

414 Nakayashiki T, Kurtzman CP, Edskes HK, and Wickner RB. 2005. Yeast prions [URE3] and [PSI+] are diseases. Proc Natl Acad Sci U S A 102:10575-10580.

416 Necci M, Piovesan D, Dosztanyi Z, Tompa P, and Tosatto SCE. 2018. A comprehensive 417 assessment of long intrinsic protein disorder from the DisProt database. Bioinformatics 418 34:445-452. 10.1093/bioinformatics/btx590 
419 Oldfield CJ, and Dunker AK. 2014. Intrinsically disordered proteins and intrinsically disordered 420 protein regions. Annu Rev Biochem 83:553-584. 10.1146/annurev-biochem-072711164947

422 Osherovich LZ, and Weissman JS. 2001. Multiple Gln/Asn-rich prion domains confer 423 susceptibility to induction of the yeast [PSI(+)] prion. Cell 106:183-194. 10.1016/s00928674(01)00440-8

425

426

427

428

429

430

431

432

433

434

435

436

437

438

439

440

441

Pallares I, de Groot NS, Iglesias V, Sant'Anna R, Biosca A, Fernandez-Busquets X, and Ventura S. 2018. Discovering Putative Prion-Like Proteins in Plasmodium falciparum: A Computational and Experimental Analysis. Front Microbiol 9:1737. 10.3389/fmicb.2018.01737

Pokrishevsky E, Grad LI, and Cashman NR. 2016. TDP-43 or FUS-induced misfolded human wild-type SOD1 can propagate intercellularly in a prion-like fashion. Sci Rep 6:22155. $10.1038 /$ srep 22155

Ross ED, Baxa U, and Wickner RB. 2004. Scrambled prion domains form prions and amyloid. Mol Cell Biol 24:7206-7213. 10.1128/MCB.24.16.7206-7213.2004

Ross ED, Maclea KS, Anderson C, and Ben-Hur A. 2013. A bioinformatics method for identifying Q/N-rich prion-like domains in proteins. Methods Mol Biol 1017:219-228. $10.1007 / 978-1-62703-438-8+16$

Saupe SJ. 2011. The [Het-s] prion of Podospora anserina and its role in heterokaryon incompatibility. Semin Cell Dev Biol 22:460-468. 10.1016/j.semcdb.2011.02.019

Shahnawaz M, Park KW, Mukherjee A, Diaz-Espinoza R, and Soto C. 2017. Prion-like characteristics of the bacterial protein Microcin E492. Sci Rep 7:45720. $10.1038 /$ srep45720 
442 Shen XX, Zhou X, Kominek J, Kurtzman CP, Hittinger CT, and Rokas A. 2016. Reconstructing 443 the Backbone of the Saccharomycotina Yeast Phylogeny Using Genome-Scale Data. G3 (Bethesda) 6:3927-3939. 10.1534/g3.116.034744

445

446

447

448

449

450

451

452

453

454

455

456

457

458

460

461

462

463

Shida T, Kamatari YO, Yoda T, Yamaguchi Y, Feig M, Ohhashi Y, Sugita Y, Kuwata K, and Tanaka M. 2020. Short disordered protein segment regulates cross-species transmission of a yeast prion. Nat Chem Biol. 10.1038/s41589-020-0516-y

Shorter J, and Lindquist S. 2005. Prions as adaptive conduits of memory and inheritance. Nat Rev Genets 6:435-450.

Si K, Choi YB, White-Grindley E, Majumdar A, and Kandel ER. 2010. Aplysia CPEB can form prion-like multimers in sensory neurons that contribute to long-term facilitation. Cell 140:421-435. 10.1016/j.cell.2010.01.008

Sideri T, Yashiroda Y, Ellis DA, Rodriguez-Lopez M, Yoshida M, Tuite MF, and Bahler J. 2017. The copper transport-associated protein Ctr4 can form prion-like epigenetic determinants in Schizosaccharomyces pombe. Microb Cell 4:16-28. $10.15698 / \operatorname{mic} 2017.01 .552$

Stansfield I, Jones KM, Kushnirov VV, Dagkesamanskaya AR, Poznyakovski AI, Paushkin SV, Nierras CR, Cox BS, Ter-Avanesyan MD, and Tuite MF. 1995. The products of the SUP45 (eRF1) and SUP35 genes interact to mediate translation termination in Saccharomyces cerevisiae. EMBO J 14:4365-4373.

Su TY, and Harrison PM. 2019. Conservation of Prion-Like Composition and Sequence in PrionFormers and Prion-Like Proteins of Saccharomyces cerevisiae. Front Mol Biosci 6:54. 10.3389/fmolb.2019.00054 
464 Su WC, and Harrison PM. 2020. Deep conservation of prion-like composition in the eukaryotic 465 prion-former Pub1/Tial family and its relatives. PeerJ 8:e9023. 10.7717/peerj.9023

466 Sun Z, Diaz Z, Fang X, Hart MP, Chesi A, Shorter J, and Gitler AD. 2011. Molecular

467 determinants and genetic modifiers of aggregation and toxicity for the ALS disease

468 protein FUS/TLS. PLoS Biol 9:e1000614. 10.1371/journal.pbio.1000614

469 Tetz G, and Tetz V. 2017. Prion-Like Domains in Phagobiota. Front Microbiol 8:2239.

470 10.3389/fmicb.2017.02239

471 Tetz G, and Tetz V. 2018. Prion-like Domains in Eukaryotic Viruses. Sci Rep 8:8931.

472 $10.1038 / \mathrm{s} 41598-018-27256-\mathrm{w}$

Toombs JA, McCarty BR, and Ross ED. 2010. Compositional determinants of prion formation in yeast. Mol Cell Biol 30:319-332. 10.1128/MCB.01140-09

475 True H, Berlin I, and Lindquist S. 2004. Epigenetic regulation of translation reveals hidden genetic variation to produce comlex traits. Nature 431:184-187.

True H, and Lindquist S. 2000. A yeast prion provides a mechanism for genetic variation and phenotypic diversity. Nature 407:477-483.

Watts JC. 2019. Calling alpha-synuclein a prion is scientifically justifiable. Acta Neuropathol 138:505-508. 10.1007/s00401-019-02058-0

Westaway D, Daude N, Wohlgemuth S, and Harrison P. 2011. The PrP-like proteins Shadoo and 482 Doppel. Top Curr Chem 305:225-256. 10.1007/128_2011_190

Wickner R. 1994. [URE3] as an altered URE2 protein: evidence for a prion analog in Saccharomyces cerevisiae. Science 264:528-530. proteins as genes and infectious entities. Genes Dev 18:470-485. 
487 Yuan AH, Garrity SJ, Nako E, and Hochschild A. 2014. Prion propagation can occur in a 488 prokaryote and requires the ClpB chaperone. Elife 3:e02949. 10.7554/eLife.02949

489 Yuan AH, and Hochschild A. 2017. A bacterial global regulator forms a prion. Science 355:198$490 \quad$ 201. $10.1126 /$ science.aai7776

491 Zambrano R, Conchillo-Sole O, Iglesias V, Illa R, Rousseau F, Schymkowitz J, Sabate R, Daura $492 \quad$ X, and Ventura S. 2015. PrionW: a server to identify proteins containing 493 glutamine/asparagine rich prion-like domains and their amyloid cores. Nucleic Acids Res $494 \quad$ 43:W331-337. 10.1093/nar/gkv490

495 Zhouravleva G, Frolova L, Le Goff X, Le Guellec R, Inge-Vechtomov S, Kisselev L, and 496 Philippe M. 1995. Termination of translation in eukaryotes is governed by two interacting 497 polypeptide chain release factors, eRF1 and eRF3. EMBOJ 14:4065-4072. 
Figure 1

Correlation of various measures of mutational bias across proteomes versus the individual compositional bias in the Ure2p prion-forming domain, as judged by the fLPS program.

The outlier proteome $A$. rubescens is ringed. (a) Percentage of poly- $\mathrm{N}$ residues in the proteome. (b) Percentage of (poly-N + poly-Q) residues in the proteome. (c) DNA GC\%. (d) Fraction of N/Q-rich prion-like proteins with fLPS P-value <1e-10. (e) Table of correlations and significances for plots (a) to (d).

(A)

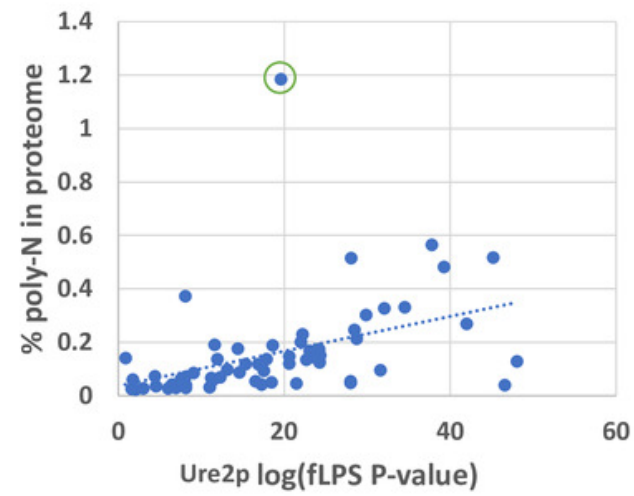

(B)

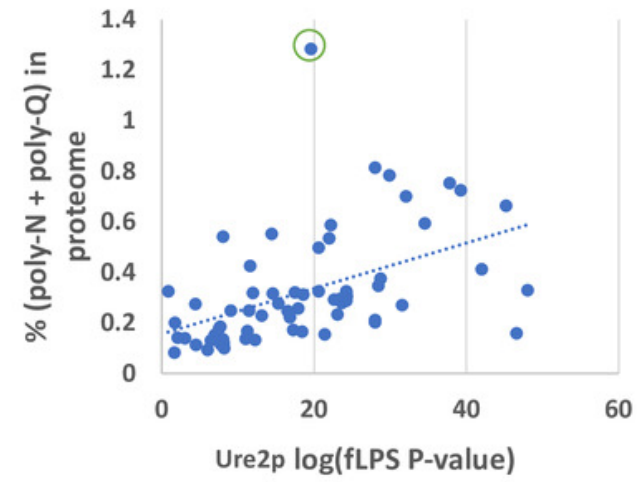

(C)

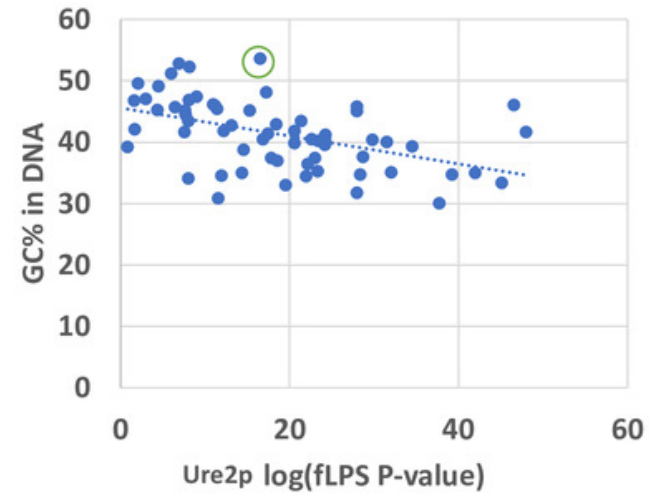

(D)

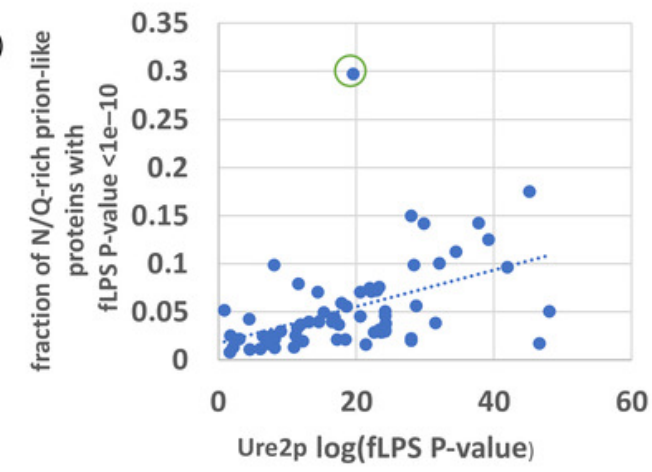

(E)

\begin{tabular}{|l|l|l|l|l|}
\hline & $\begin{array}{l}\text { Percentage of polyN in } \\
\text { the proteome }\end{array}$ & $\begin{array}{l}\text { Percentage of } \\
\text { (polyN+polyQ) in the } \\
\text { proteome }\end{array}$ & $\begin{array}{l}\text { Fraction of prion-like } \\
\text { domains flPS P-value } \\
\leq 10^{-10}\end{array}$ & GC\% in DNA \\
\hline Log(fLPS P-value) & $0.468(P=0.00074)$ & $0.527(P<0.00001)$ & $0.535(P<0.00001)$ & $-0.570(P<0.00001)$ \\
\hline
\end{tabular}


Figure 2

As in Figure 1, except versus the individual PLAAC PRDscore in the Ure2p prion-forming domain.

The outlier proteome $A$. rubescens is ringed. (a) Percentage of poly-N residues in the proteome. (b) Percentage of (poly-N + poly-Q) residues in the proteome. (c) DNA GC\%. (d) Fraction of proteome with PLAAC score $\geq 15.0$. (e) Table of correlations and significances for plots (a) to (d).

(A)

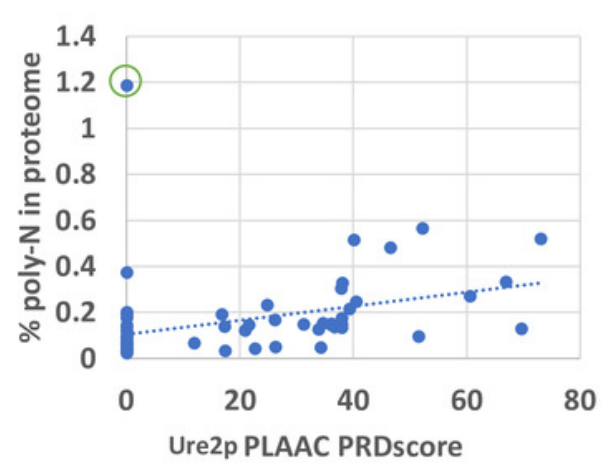

(B)

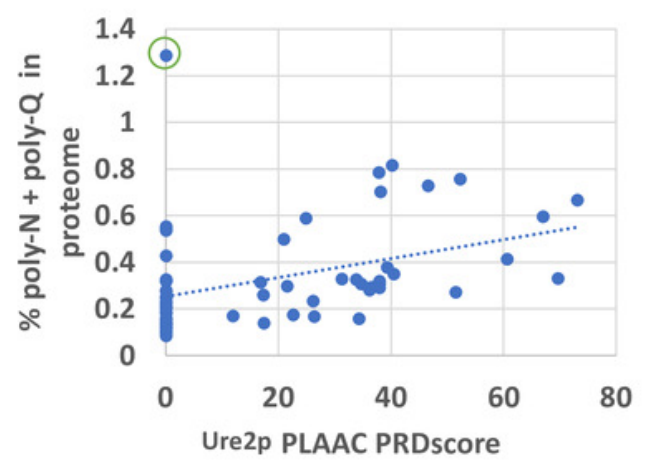

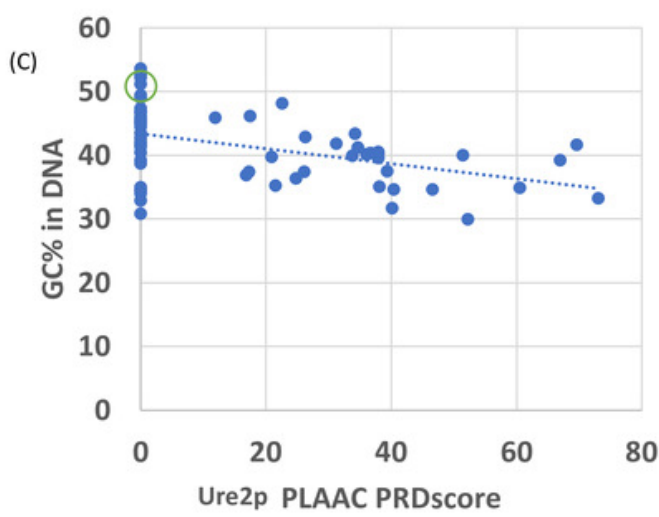

(D)

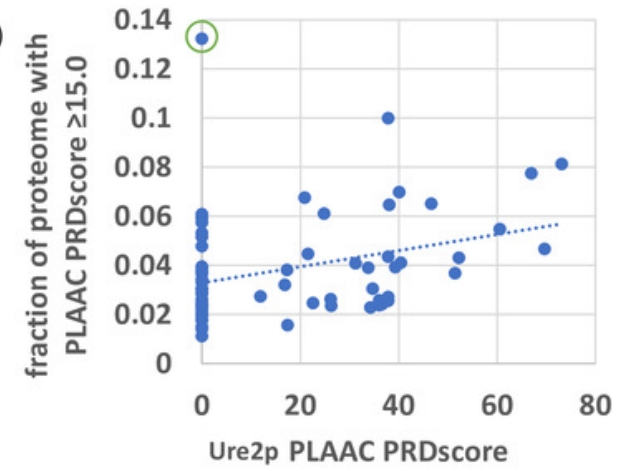

(E)

\begin{tabular}{|l|l|l|l|l|}
\hline & $\begin{array}{l}\text { Fraction of polyN in } \\
\text { proteome }\end{array}$ & $\begin{array}{l}\text { Fraction of } \\
\text { (poly }+ \text { polya) }\end{array}$ & $\begin{array}{l}\text { Fraction of prion-like domains } \\
\text { fPLAAC PRD score } \geq 15.0\end{array}$ & GC\% in DNA \\
\hline Log(fLPS P-value) $)$ & $0.388(\mathrm{P}=0.0013)$ & $0.441(\mathrm{P}=0.00021)$ & $0.424(\mathrm{P}=0.00039)$ & $-0.539(\mathrm{P}<0.00001)$ \\
\hline
\end{tabular}


Figure 3

Schematic evolutionary tree for Ure2p, showing the distribution of orthologs with prionlike composition in different evolutionary families in the Uniprot reference set of fungal proteomes.

The number of species in each family is given in brackets. The numbers of orthologs that are have fLPS P-value $\leq 1 \mathrm{e}-10$ and PLAAC score $\geq 15.0$ are listed in columns.

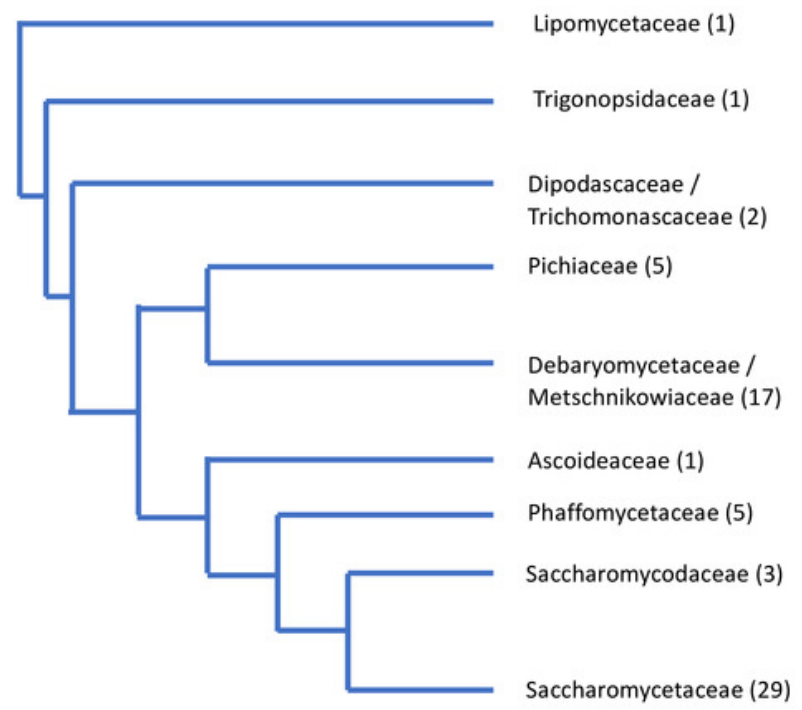

$\begin{array}{ll}0 & 0 \\ 0 & 0 \\ 1 & 1 \\ 0 & 0 \\ 6(35 \%) & 7(41 \%) \\ 1 & 1 \\ 0 & 0 \\ 3(100 \%) & 3(100 \%) \\ 25(86 \%) & 24(83 \%)\end{array}$




\section{Figure 4}

Analysis of fraction of $\mathrm{K}$ (lysine) residues.

\section{(A) Scatter plots of fraction of $\mathrm{K}$ within the N/Q-rich regions of prion-forming} domains plotted versus the overall fraction of $\mathbf{K}$ in proteomes. Blue points are for the set of known amyloid-based prions in Figure 4, and orange points for the total list of prionforming domains including those listed in Table S2. The $x=y$ line is indicated.

Histograms for the data in (A). The same colour scheme is kept, except that the data for the rest of the proteome is in grey. Each bin is labelled with its higher bound. 
(A)

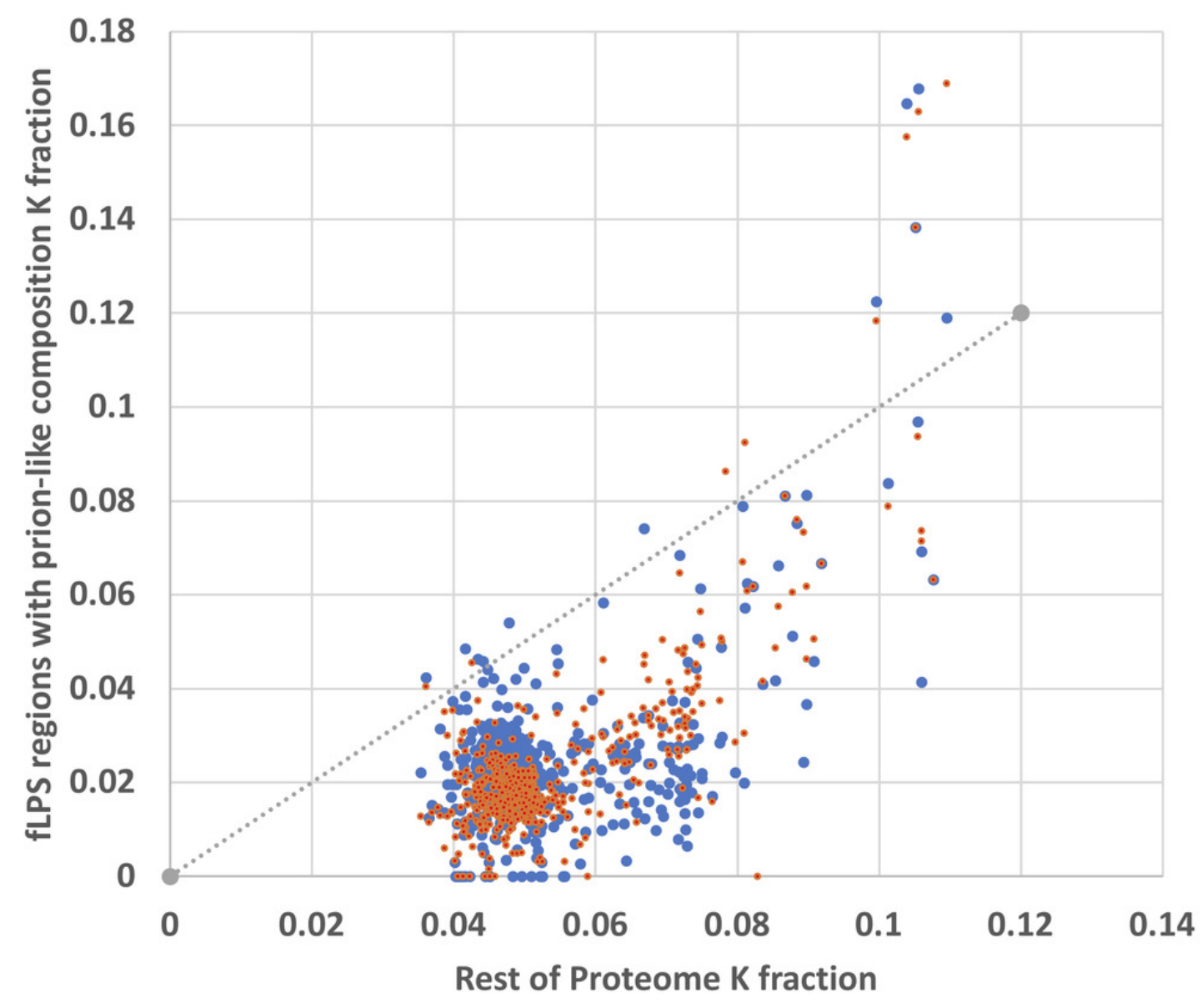

(B)

250

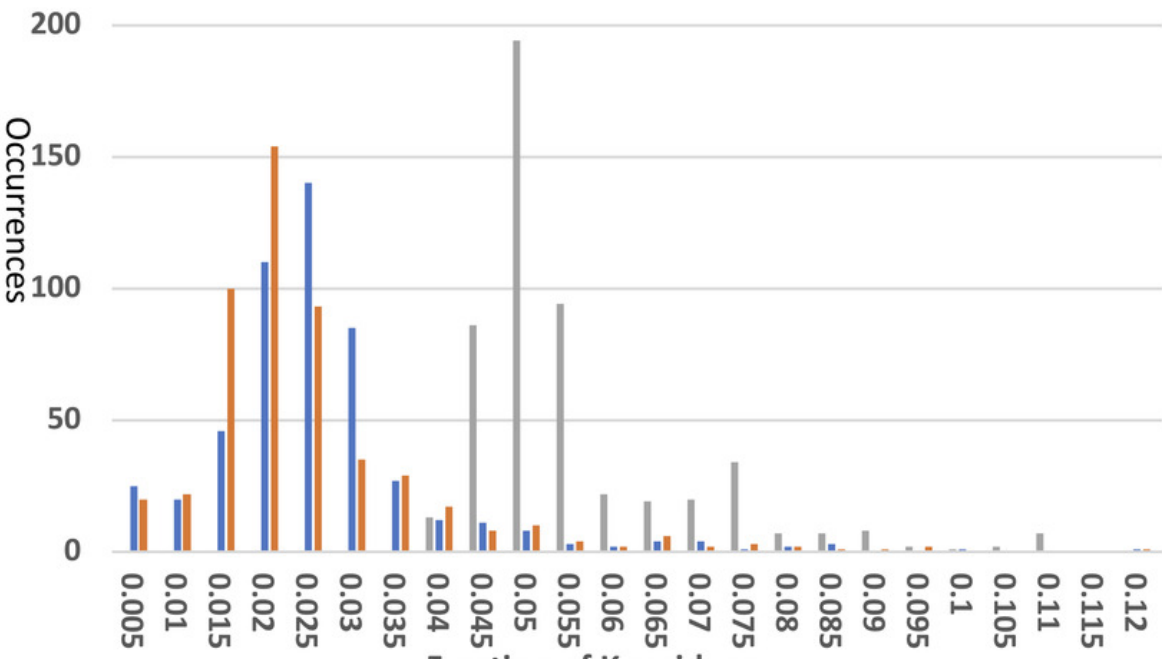

Fraction of $\mathrm{K}$ residues 


\section{Table $\mathbf{1}$ (on next page)}

Table for a set of known prion-forming domains of the correlations (weighted and unweighted) between the compositional bias (-log[fLPS P-value]), and a variety of parameters.

Weighted correlations are the upper value in each cell, unweighted the lower value. Where removal of the common far outlier species Ascoidea rubescens causes increased significance for any correlation, the third and fourth rows in a cell display the correlation coefficients (in italics). For proteins which do not have an ortholog from Ascoidea rubescens, the name is labelled with ' $t+$ '. If its removal causes no improvement in correlations, it is labelled with ' $t$ '. Correlations significant at $\leq 0.0005$ are labelled *** and in bold, significant at $>0.0005$ and $\leq 0.0016$ labelled $* *$ and underlined, and $>0.0016$, and $\leq 0.05$ are labelled $*$ ). The threshold 0.0016 comes from a Bonferroni correction to allow for the fact that 31 sequences are being tested for a correlation against any specific proteome-wide property. In column one, the name is styled according to the most significant correlation. 


\begin{tabular}{|c|c|c|c|c|c|c|c|c|c|c|c|}
\hline \multirow{2}{*}{$\begin{array}{l}\text { Protein } \\
\text { (Number of } \\
\text { orthologs } \\
\text { in } \\
\text { brackets) }\end{array}$} & \multirow[t]{2}{*}{$\begin{array}{l}\text { Weighted } \\
\text { correlation } \\
\text { (Y/N)? }\end{array}$} & \multirow{2}{*}{$\begin{array}{l}\text { A. } \\
\text { rubescens } \\
\text { excluded } \\
(\mathrm{Y} / \mathrm{N}) ?\end{array}$} & \multirow[t]{2}{*}{$\begin{array}{l}\% \mathrm{~N} \\
\text { in } \\
\text { proteome }\end{array}$} & \multirow[t]{2}{*}{\begin{tabular}{|l|}
$\% Q$ \\
in \\
proteome
\end{tabular}} & \multirow[t]{2}{*}{$\%$ poly-N } & \multirow[t]{2}{*}{ \%poly-Q } & \multirow[t]{2}{*}{$\begin{array}{l}\text { \%poly-Q } \\
+ \\
\% \text { poly-N }\end{array}$} & \multirow[t]{2}{*}{ DNA GC\% } & \multicolumn{3}{|c|}{$\begin{array}{l}\text { Fraction of N/Q-rich proteins in } \\
\text { the proteome by fLPS bias } \\
\text { threshold P-value }\end{array}$} \\
\hline & & & & & & & & & $\geq 1 \mathrm{e}-08$ & $\geq 1 \mathrm{e}-10$ & $\geq 1 \mathrm{e}-12$ \\
\hline \multicolumn{12}{|c|}{ Known amyloid-based prions in S. cerevisiae } \\
\hline$\frac{\text { Sup35 }}{\text { P05453 }}$ & $\begin{array}{l}\mathrm{Y} \\
\mathrm{N} \\
\mathrm{Y} \\
\mathrm{N}\end{array}$ & $\begin{array}{l}\mathrm{N} \\
\mathrm{N} \\
\mathrm{Y} \\
\mathrm{Y}\end{array}$ & $\begin{array}{l}0.237 \\
0.136 \\
0.350 \text { * } \\
0.316 \text { * }\end{array}$ & \begin{tabular}{|l|}
0.042 \\
0.060 \\
0.019 \\
0.021 \\
\end{tabular} & $\begin{array}{l}0.132 \\
0.035 \\
0.315 \text { * } \\
0.307 \text { * } \\
\end{array}$ & $\begin{array}{l}\frac{0.415^{* *}}{0.380^{*}} \\
\underline{0.411^{* *}} \\
0.370^{*}\end{array}$ & $\begin{array}{l}0.278^{*} \\
0.180^{*} \\
\underline{0.409^{* *}} \\
0.385^{*}\end{array}$ & $\begin{array}{l}-0.351^{*} \\
-0.263^{*} \\
-0.388^{*} \\
-0.323^{*}\end{array}$ & $\begin{array}{l}0.218 \\
0.142 \\
0.348 \text { * } \\
0.348 \text { * }\end{array}$ & $\begin{array}{l}0.202 \\
0.119 \\
0.353 \text { * } \\
0.356 \text { * }\end{array}$ & $\begin{array}{l}0.187 \\
0.095 \\
0.366 \text { * } \\
0.368 \text { * }\end{array}$ \\
\hline $\begin{array}{l}\text { Swi1 t† } \\
\text { P09547 } \\
\text { (56) }\end{array}$ & $\begin{array}{l}\mathrm{Y} \\
\mathrm{N}\end{array}$ & $\begin{array}{l}\mathrm{N} \\
\mathrm{N}\end{array}$ & $\begin{array}{l}0.661^{* * *} \\
0.628 \text { *** }\end{array}$ & $\begin{array}{l}-0.149 \\
-0.184\end{array}$ & $\begin{array}{l}0.603 * * * \\
0.570 * * *\end{array}$ & $\begin{array}{l}0.074 \\
0.016\end{array}$ & $\begin{array}{l}0.544 * * * \\
0.473^{* * *}\end{array}$ & $\begin{array}{l}-0.498^{* * *} \\
-0.510^{* * *}\end{array}$ & $\begin{array}{l}0.643^{* * *} \\
0.600^{* * *}\end{array}$ & $\begin{array}{l}0.627^{* * *} \\
0.586 * * *\end{array}$ & $\begin{array}{l}0.607 * * * \\
0.568 * * *\end{array}$ \\
\hline $\begin{array}{l}\text { Cyc8 } \\
\text { P14922 } \\
(61)\end{array}$ & $\begin{array}{l}\mathrm{Y} \\
\mathrm{N} \\
\mathrm{Y} \\
\mathrm{N}\end{array}$ & $\begin{array}{l}\mathrm{N} \\
\mathrm{N} \\
\mathrm{Y} \\
\mathrm{Y}\end{array}$ & $\begin{array}{l}0.387^{*} \\
0.251 \\
0.522 \text { *** } \\
0.368 \text { * }\end{array}$ & $\begin{array}{l}0.292 \text { * } \\
0.320 \text { * } \\
0.278 \text { * } \\
0.307 \text { * }\end{array}$ & $\begin{array}{l}0.320 \text { * } \\
0.165 \\
0.577 \text { *** } \\
0.350 \text { * }\end{array}$ & $\begin{array}{l}0.361 \text { * } \\
0.305 \text { * } \\
0.354 \text { * } \\
0.297^{*}\end{array}$ & $\begin{array}{l}\frac{0.409^{* *}}{0.254^{*}} \\
0.567^{* * *} \\
0.382^{*}\end{array}$ & $\begin{array}{l}-0.472 \text { *** } \\
-0.305^{*} \\
-0.507^{* * *} \\
-0.334^{*}\end{array}$ & $\begin{array}{l}\frac{0.398^{* *}}{0.240} \\
0.563^{* * *} \\
0.374^{*}\end{array}$ & $\begin{array}{l}0.385^{*} \\
0.234 \\
0.581 \text { *** } \\
0.394^{*}\end{array}$ & $\begin{array}{l}0.364^{*} \\
0.225 \\
0.595^{* * *} \\
0.418^{* *}\end{array}$ \\
\hline $\begin{array}{l}\text { Ure2 } \\
\text { P23202 } \\
(66)\end{array}$ & $\begin{array}{l}\mathrm{Y} \\
\mathrm{N} \\
\mathrm{Y} \\
\mathrm{N}\end{array}$ & $\begin{array}{l}\mathrm{N} \\
\mathrm{N} \\
\mathrm{Y} \\
\mathrm{Y}\end{array}$ & $\begin{array}{l}0.571^{* * *} \\
0.485 * * * \\
0.682 * * * \\
0.566 \text { *** }\end{array}$ & $\begin{array}{l}0.241 \\
0.253 \text { * } \\
0.246 \text { * } \\
0.259 \text { * }\end{array}$ & $\begin{array}{l}0.468 * * * \\
0.420 * * * \\
0.676 * * * \\
0.590 * * *\end{array}$ & $\begin{array}{l}0.357^{*} \\
0.330 \text { * } \\
0.361 \text { * } \\
0.332 \text { * }\end{array}$ & $\begin{array}{l}0.527 * * * \\
0.476 \text { *** } \\
0.651 \text { *** } \\
0.563^{* * *}\end{array}$ & $\begin{array}{l}-0.570^{* * *} \\
-0.478^{* * *} \\
-0.584^{* * *} \\
-0.484^{* * *}\end{array}$ & $\begin{array}{l}0.556 \text { *** } \\
0.470 \text { *** } \\
0.687 \text { *** } \\
0.568 \text { *** }\end{array}$ & $\begin{array}{l}0.535 * * * \\
0.453 * * * \\
0.696 * * * \\
0.576 * * *\end{array}$ & $\begin{array}{l}0.495 * * * \\
0.423 * * * \\
0.690 * * * \\
0.572 \text { *** }\end{array}$ \\
\hline $\begin{array}{l}\text { Rnq1 † } \\
\text { P25367 } \\
(26)\end{array}$ & $\begin{array}{l}\mathrm{Y} \\
\mathrm{N}\end{array}$ & $\begin{array}{l}\mathrm{N} \\
\mathrm{N}\end{array}$ & $\begin{array}{l}0.139 \\
0.230\end{array}$ & $\begin{array}{l}-0.381 \\
-0.431\end{array}$ & $\begin{array}{l}0.096 \\
0.159\end{array}$ & $\begin{array}{l}-0.193 \\
-0.197\end{array}$ & $\begin{array}{l}0.037 \\
0.090\end{array}$ & $\begin{array}{l}-0.080 \\
-0.159\end{array}$ & $\begin{array}{l}0.081 \\
0.070\end{array}$ & \begin{tabular}{|l|}
0.053 \\
0.040
\end{tabular} & $\begin{array}{l}0.010 \\
0.001\end{array}$ \\
\hline $\begin{array}{l}\text { Mot3 † } \\
\text { P54785 } \\
(25)\end{array}$ & $\begin{array}{l}\mathrm{Y} \\
\mathrm{N}\end{array}$ & $\begin{array}{l}\mathrm{N} \\
\mathrm{N}\end{array}$ & $\begin{array}{l}0.460 \text { * } \\
0.393\end{array}$ & $\begin{array}{l}-0.420^{*} \\
-0.507^{*}\end{array}$ & $\begin{array}{l}0.395 \\
0.264\end{array}$ & $\begin{array}{l}0.371 \\
0.268\end{array}$ & $\begin{array}{l}0.439 * \\
0.299\end{array}$ & $\begin{array}{l}-0.468 \text { * } \\
-0.409 *\end{array}$ & $\begin{array}{l}0.385 \\
0.140\end{array}$ & $\begin{array}{l}0.386 \\
0.129\end{array}$ & $\begin{array}{l}0.399 * \\
0.146\end{array}$ \\
\hline $\begin{array}{l}\text { Nu100 } † \\
\text { Q02629 } \\
(11)\end{array}$ & $\begin{array}{l}\mathrm{Y} \\
\mathrm{N}\end{array}$ & $\begin{array}{l}N \\
N\end{array}$ & $\begin{array}{l}0.154 \\
0.224\end{array}$ & \begin{tabular}{|l|}
0.107 \\
0.148
\end{tabular} & $\begin{array}{l}-0.110 \\
-0.058\end{array}$ & $\begin{array}{l}-0.105 \\
0.013\end{array}$ & $\begin{array}{l}-0.518 \\
-0.499\end{array}$ & $\begin{array}{l}-0.008 \\
-0.090\end{array}$ & $\begin{array}{l}-0.012 \\
-0.017\end{array}$ & $\begin{array}{l}-0.027 \\
-0.030\end{array}$ & $\begin{array}{l}-0.047 \\
-0.042\end{array}$ \\
\hline $\begin{array}{l}\text { Pin3 † } \\
\text { Q06449 } \\
(55)\end{array}$ & $\begin{array}{l}\mathrm{Y} \\
\mathrm{N}\end{array}$ & $\begin{array}{l}\mathrm{N} \\
\mathrm{N}\end{array}$ & $\begin{array}{l}0.198 \\
0.179\end{array}$ & \begin{tabular}{|l|}
0.022 \\
-0.030
\end{tabular} & \begin{tabular}{|l|}
0.230 \\
0.200
\end{tabular} & $\begin{array}{l}0.000 \\
-0.014\end{array}$ & $\begin{array}{l}-0.121 \\
-0.046\end{array}$ & $\begin{array}{l}-0.183 \\
-0.169\end{array}$ & $\begin{array}{l}0.209 \\
0.165\end{array}$ & $\begin{array}{l}0.198 \\
0.153\end{array}$ & $\begin{array}{l}0.179 \\
0.137\end{array}$ \\
\hline
\end{tabular}


Other prion-forming domains discussed in the text

\begin{tabular}{|c|c|c|c|c|c|c|c|c|c|c|c|}
\hline $\begin{array}{l}\text { New1 } \\
\text { †† } \\
\text { Q08972 } \\
(63)\end{array}$ & $\begin{array}{l}\mathrm{Y} \\
\mathrm{N}\end{array}$ & $\begin{array}{l}\mathrm{N} \\
\mathrm{N}\end{array}$ & $\begin{array}{l}0.566 * * * \\
0.521 * * *\end{array}$ & $\begin{array}{l}0.269 \text { * } \\
0.261 \text { * }\end{array}$ & $\begin{array}{l}0.476 * * * \\
0.442 \text { *** }\end{array}$ & $\begin{array}{l}0.191 \\
0.188\end{array}$ & $\begin{array}{l}0.482 * * * \\
0.439 * * *\end{array}$ & $\begin{array}{l}-0.482 * * * \\
-0.449 * * *\end{array}$ & $\begin{array}{l}0.513 \text { *** } \\
0.468 \text { *** }\end{array}$ & $\begin{array}{l}0.501 * * * \\
0.458 \text { *** }\end{array}$ & $\begin{array}{l}0.486 \text { *** } \\
0.446 \text { *** }\end{array}$ \\
\hline $\begin{array}{l}\text { Pub1 } \\
\text { P32588 } \\
\text { (62) }\end{array}$ & $\begin{array}{l}\mathrm{Y} \\
\mathrm{N} \\
\mathrm{Y} \\
\mathrm{N}\end{array}$ & $\begin{array}{l}\mathrm{N} \\
\mathrm{N} \\
\mathrm{Y} \\
\mathrm{Y}\end{array}$ & $\begin{array}{l}0.469 * * * \\
0.457 * * * \\
0.466 * * * \\
0.450 \text { *** }\end{array}$ & $\begin{array}{l}0.365^{*} \\
0.243 \\
0.401^{* *} \\
0.278 \text { * }\end{array}$ & $\begin{array}{l}0.484^{* * *} \\
0.426^{* *} \\
0.551 * * * \\
0.459 * * *\end{array}$ & $\begin{array}{l}0.707 * * * \\
0.620 \text { *** } \\
0.734 \text { *** } \\
0.646 \text { *** }\end{array}$ & $\begin{array}{l}0.686 * * * \\
0.597 * * * \\
0.728 * * * \\
0.622 * * *\end{array}$ & $\begin{array}{l}-0.547 * * * \\
-0.532 * * * \\
-0.534 * * * \\
-0.518\end{array}$ & $\begin{array}{l}0.545 * * * \\
0.449 * * * \\
0.567 * * * \\
0.447 \text { *** }\end{array}$ & $\begin{array}{l}0.545 * * * \\
0.448 * * * \\
0.584 \text { *** } \\
0.459 * *\end{array}$ & $\begin{array}{l}0.533 \text { *** } \\
0.442 \text { *** } \\
0.594 \text { *** } \\
0.471 \text { *** }\end{array}$ \\
\hline
\end{tabular}




\section{Table 2 (on next page)}

Table for a set of known prion-forming domains of the correlations (both weighted and un-weighted) between the prion-like composition (PLAAC PRDscore) and a variety of parameters.

Weighted correlations are the upper value in each cell, unweighted the lower value. Where removal of the common far outlier species Ascoidea rubescens causes increased significance for any correlation, the third and fourth rows in a cell display the correlation coefficients (in italics). For proteins which do not have an ortholog from Ascoidea rubescens, the name is labelled with ' $t+$ '. If its removal causes no improvement in correlations, it is labelled with ' $t$ '. Correlations significant at $\leq 0.0005$ are labelled $* * *$ and in bold, significant at $>0.0005$ and $\leq 0.0016$ labelled $* *$ and underlined, and $>0.0016$, and $\leq 0.05$ are labelled $*$ ). The threshold 0.0016 comes from a Bonferroni correction to allow for the fact that 31 sequences are being tested for a correlation against any specific proteome-wide property. In column one, the name is styled according to the most significant correlation. 


\begin{tabular}{|c|c|c|c|c|c|c|c|c|c|c|c|}
\hline \multirow{2}{*}{$\begin{array}{l}\text { Protein } \\
\text { (Number } \\
\text { of } \\
\text { orthologs } \\
\text { in } \\
\text { brackets) }\end{array}$} & \multirow[t]{2}{*}{$\begin{array}{l}\text { Weighted } \\
\text { correlation } \\
(\mathrm{Y} / \mathrm{N}) ?\end{array}$} & \multirow[t]{2}{*}{$\begin{array}{l}\text { A. } \\
\text { extiscens } \\
\text { excluded } \\
\text { (Y/N)? }\end{array}$} & \multirow[t]{2}{*}{$\begin{array}{l}\% \mathrm{~N} \text { in } \\
\text { proteome }\end{array}$} & \multirow[t]{2}{*}{$\begin{array}{l}\% Q \text { in } \\
\text { proteome }\end{array}$} & \multirow[t]{2}{*}{$\begin{array}{l}\text { \%poly- } \\
\mathrm{N}\end{array}$} & \multirow[t]{2}{*}{$\begin{array}{l}\text { \%poly- } \\
\text { Q Vlanus }\end{array}$} & \multirow[t]{2}{*}{$\begin{array}{l}\text { \%poly-Q } \\
\text { r.ppt to be } \\
\text { \%poly-N }\end{array}$} & \multirow[t]{2}{*}{$\begin{array}{l}\text { DNA } \\
\text { ece } \text { Co }\end{array}$} & \multicolumn{3}{|c|}{$\begin{array}{l}\text { Fraction of prion-like } \\
\text { proteins in the proteome by } \\
\text { PLAAC PRDscore }\end{array}$} \\
\hline & & & & & & & & & $>0.0$ & $\geq 15.0$ & $\geq 30.0$ \\
\hline \multicolumn{12}{|c|}{ Known amyloid-based prions in S. cerevisiae } \\
\hline $\begin{array}{l}\text { Sup35 } \\
\text { P05453 } \\
(62)\end{array}$ & $\begin{array}{l}\mathrm{Y} \\
\mathrm{N} \\
\mathrm{Y} \\
\mathrm{N}\end{array}$ & \begin{tabular}{|l}
$\mathrm{N}$ \\
$\mathrm{N}$ \\
$\mathrm{Y}$ \\
$\mathrm{Y}$
\end{tabular} & $\begin{array}{l}0.292^{*} \\
0.160 \\
0.457^{* * *} \\
0.407^{* *}\end{array}$ & $\begin{array}{l}0.268 \text { * } \\
0.254 \text { * } \\
0.245 \\
0.215\end{array}$ & $\begin{array}{l}0.174 \\
0.040 \\
0.437 * * * \\
0.411 * * \\
\end{array}$ & $\begin{array}{l}\underline{0.423^{* *}} \\
0.372^{*} \\
0.421^{* *} \\
0.363^{*}\end{array}$ & $\begin{array}{l}0.313^{*} \\
0.181 \\
\mathbf{0 . 4 9 7} * * * \\
\mathbf{0 . 4 5 4} * * *\end{array}$ & $\begin{array}{l}-0.345^{*} \\
-0.252^{*} \\
-0.401^{* *} \\
-0.336^{*}\end{array}$ & $\begin{array}{l}0.429 * * * \\
0.307^{*} \\
0.574^{* * *} \\
\mathbf{0 . 5 2 8} * * *\end{array}$ & $\begin{array}{l}0.369 * \\
0.224 \\
0.560 * * * \\
0.506 * * *\end{array}$ & $\begin{array}{l}0.273^{*} \\
0.108^{*} \\
\mathbf{0 . 5 2 5} * * * \\
\mathbf{0 . 4 6 1} * * *\end{array}$ \\
\hline $\begin{array}{l}\text { Swi1 †† } \\
\text { P09547 } \\
\text { (56) }\end{array}$ & $\begin{array}{l}\mathrm{Y} \\
\mathrm{N}\end{array}$ & $\begin{array}{l}\mathrm{N} \\
\mathrm{N}\end{array}$ & $\begin{array}{l}0.475 * * * \\
0.465 * * *\end{array}$ & $\begin{array}{l}-0.206 \\
-0.200\end{array}$ & $\begin{array}{l}\mathbf{0 . 4 5 1} * * * \\
0.431^{* *}\end{array}$ & $\begin{array}{l}0.074 \\
0.054\end{array}$ & $\frac{0.414^{* *}}{0.375^{*}}$ & $\begin{array}{l}-0.471^{* * *} \\
-0.470^{* * *}\end{array}$ & $\begin{array}{l}0.460 \text { *** } \\
0.443^{* *}\end{array}$ & $\begin{array}{l}0.464^{* * *} \\
0.441^{* *}\end{array}$ & $\frac{0.442^{* *}}{0.411^{*}}$ \\
\hline $\begin{array}{l}\text { Cyc8 } \\
\text { P14922 } \\
(61)\end{array}$ & $\begin{array}{l}\mathrm{Y} \\
\mathrm{N} \\
\mathrm{Y} \\
\mathrm{N}\end{array}$ & $\begin{array}{l}N \\
N \\
Y \\
Y\end{array}$ & $\begin{array}{l}0.353^{*} \\
0.244 \\
0.453^{* * *} \\
0.328^{*}\end{array}$ & $\begin{array}{l}0.250 \\
0.285 \text { * } \\
0.242 \\
0.279 \text { * }\end{array}$ & $\begin{array}{l}0.325^{*} \\
0.183 \\
0.535 \text { *** } \\
0.324^{*}\end{array}$ & $\begin{array}{l}\frac{0.421^{* *}}{0.356^{*}} \\
\underline{0.417^{* *}} \\
0.353^{*}\end{array}$ & $\begin{array}{l}\mathbf{0 . 4 3 8} \text { *** } \\
0.288^{*} \\
\mathbf{0 . 5 6 9} * * * \\
0.389^{*}\end{array}$ & $\begin{array}{l}-0.458^{* * *} \\
-0.301^{*} \\
-0.482^{* * *} \\
-0.319^{*}\end{array}$ & $\begin{array}{l}0.563 * * * \\
0.462 * * * \\
0.645 * * * \\
0.544\end{array}$ & $\begin{array}{l}\mathbf{0 . 4 8 6} \text { *** } \\
0.385^{*} \\
\mathbf{0 . 6 0 8} \text { ***} \\
\mathbf{0 . 5 0 3} \text { ***}\end{array}$ & $\begin{array}{l}0.375^{*} \\
0.274^{*} \\
\mathbf{0 . 5 4 8} \text { ***} \\
0.429^{* *}\end{array}$ \\
\hline $\begin{array}{l}\text { Ure2 } \\
\text { P23202 } \\
(66)\end{array}$ & $\begin{array}{l}\mathrm{Y} \\
\mathrm{N} \\
\mathrm{Y} \\
\mathrm{N}\end{array}$ & $\begin{array}{l}\mathrm{N} \\
\mathrm{N} \\
\mathrm{Y} \\
\mathrm{Y}\end{array}$ & $\begin{array}{l}0.495 * * * \\
0.448 * * * \\
0.683^{* * *} \\
0.594 * * *\end{array}$ & $\begin{array}{l}0.151 \\
0.087 \\
0.130 \\
0.071\end{array}$ & $\begin{array}{l}\frac{0.388^{* *}}{0.369^{*}} \\
0.704^{* * *} \\
0.631^{* * *}\end{array}$ & $\begin{array}{l}0.308^{*} \\
0.246 \text { * } \\
0.297 \text { * } \\
0.239\end{array}$ & $\begin{array}{l}0.441^{* * *} \\
0.401^{* *} \\
0.645^{* * *} \\
0.548^{* * *}\end{array}$ & $\begin{array}{l}-0.539 \text { *** } \\
-0.453^{* * *} \\
-0.586^{* * *} \\
-0.483^{* * *}\end{array}$ & $\begin{array}{l}0.494^{* * *} \\
0.388^{* *} \\
0.627^{* * *} \\
0.484^{* * *}\end{array}$ & $\begin{array}{l}0.424 \text { *** } \\
0.333^{*} \\
0.615^{* * *} \\
0.465 \text { *** }\end{array}$ & $\begin{array}{l}0.314^{*} \\
0.226 \\
0.567^{* * *} \\
0.393^{* *} \\
\end{array}$ \\
\hline $\begin{array}{l}\text { Rnq1 † } \\
\text { P25367 } \\
(26)\end{array}$ & $\begin{array}{l}\mathrm{Y} \\
\mathrm{N}\end{array}$ & $\begin{array}{l}N \\
N\end{array}$ & $\begin{array}{l}-0.001 \\
0.079\end{array}$ & $\begin{array}{l}-0.264 \\
-0.340\end{array}$ & $\begin{array}{l}-0.046 \\
0.005\end{array}$ & $\begin{array}{l}-0.267 \\
-0.242\end{array}$ & $\begin{array}{l}-0.107 \\
-0.058\end{array}$ & $\begin{array}{l}0.035 \\
-0.027\end{array}$ & $\begin{array}{l}-0.128 \\
-0.137\end{array}$ & $\begin{array}{l}-0.128 \\
-0.139\end{array}$ & $\begin{array}{l}-0.133 \\
-0.199\end{array}$ \\
\hline $\begin{array}{l}\text { Mot3 † } \\
\text { P54785 } \\
\text { (25) }\end{array}$ & $\begin{array}{l}\mathrm{Y} \\
\mathrm{N}\end{array}$ & $\begin{array}{l}N \\
N\end{array}$ & \begin{tabular}{|l|}
0.149 \\
0.153
\end{tabular} & $\begin{array}{l}-0.166 \\
-0.336\end{array}$ & $\begin{array}{l}0.135 \\
0.057\end{array}$ & $\begin{array}{l}0.314 \\
0.213\end{array}$ & $\begin{array}{l}0.196 \\
0.103\end{array}$ & \begin{tabular}{|l|}
-0.159 \\
-0.172
\end{tabular} & $\begin{array}{l}0.114 \\
-0.107\end{array}$ & $\begin{array}{l}0.212 \\
-0.014\end{array}$ & $\begin{array}{l}0.283 \\
-0.046\end{array}$ \\
\hline $\begin{array}{l}\text { Nu100 † } \\
\text { Q02629 } \\
(11)\end{array}$ & $\begin{array}{l}\mathrm{Y} \\
\mathrm{N}\end{array}$ & $\begin{array}{l}N \\
N\end{array}$ & $\begin{array}{l}0.090 \\
0.169\end{array}$ & $\begin{array}{l}0.283 \\
0.303\end{array}$ & $\begin{array}{l}-0.185 \\
-0.122\end{array}$ & $\begin{array}{l}-0.030 \\
0.075\end{array}$ & $\begin{array}{l}-0.165 \\
-0.083\end{array}$ & $\begin{array}{l}-0.003 \\
-0.084\end{array}$ & $\begin{array}{l}0.304 \\
0.290\end{array}$ & $\begin{array}{l}0.142 \\
0.160\end{array}$ & $\begin{array}{l}0.021 \\
-0.024\end{array}$ \\
\hline $\begin{array}{l}\text { Pin3 † } \\
\text { Q06449 } \\
(55)\end{array}$ & $\begin{array}{l}\mathrm{Y} \\
\mathrm{N}\end{array}$ & $\begin{array}{l}\mathrm{N} \\
\mathrm{N}\end{array}$ & $\begin{array}{l}0.000 \\
-0.010\end{array}$ & $\begin{array}{l}0.282 \text { * } \\
0.226\end{array}$ & $\begin{array}{l}0.025 \\
0.005\end{array}$ & $\begin{array}{l}0.222 \\
0.202\end{array}$ & $\begin{array}{l}0.121 \\
0.100\end{array}$ & $\begin{array}{l}-0.081 \\
-0.067\end{array}$ & $\begin{array}{l}0.112 \\
0.006\end{array}$ & $\begin{array}{l}0.113 \\
0.029\end{array}$ & $\begin{array}{l}0.159 \\
0.056\end{array}$ \\
\hline
\end{tabular}


Other prion-forming domains discussed in the text

\begin{tabular}{|c|c|c|c|c|c|c|c|c|c|c|c|}
\hline $\begin{array}{l}\text { New1 †† } \\
\text { Q08972 } \\
(63)\end{array}$ & $\begin{array}{l}\mathrm{Y} \\
\mathrm{N}\end{array}$ & $\mathrm{N}$ & $\begin{array}{l}0.368 \text { * } \\
0.339 \text { * }\end{array}$ & $\begin{array}{l}0.236 \\
0.250 \text { * }\end{array}$ & $\begin{array}{l}0.301 \text { * } \\
0.288 \text { * }\end{array}$ & $\begin{array}{l}0.183 \\
0.226\end{array}$ & $\begin{array}{l}0.326 \text { * } \\
0.327 \text { * }\end{array}$ & $\begin{array}{l}-0.369 \text { * } \\
-0.368 \text { * }\end{array}$ & $\begin{array}{l}0.412 \text { * } \\
0.419 \text { * }\end{array}$ & $\begin{array}{l}0.377^{*} \\
0.380 \text { * }\end{array}$ & $\begin{array}{l}0.299^{*} \\
0.291 \text { * }\end{array}$ \\
\hline $\begin{array}{l}\text { Pub1 } \\
\text { P32588 (62) }\end{array}$ & $\begin{array}{l}\mathrm{Y} \\
\mathrm{N} \\
\mathrm{Y} \\
\mathrm{N}\end{array}$ & $\begin{array}{l}N \\
N \\
Y \\
Y\end{array}$ & $\begin{array}{l}0.226 \\
0.241 \\
0.232 \\
0.247\end{array}$ & $\begin{array}{l}0.521^{* * *} \\
0.424^{* *} \\
0.540^{* * *} \\
0.443^{* * *}\end{array}$ & $\begin{array}{l}0.300 \text { * } \\
0.255^{*} \\
0.381 \text { * } \\
0.290 \text { * }\end{array}$ & $\begin{array}{l}0.756 * * * \\
0.679 * * * \\
0.771 * * * \\
0.703 * * *\end{array}$ & $\begin{array}{l}0.559 * * * \\
0.479 * * * \\
0.628 * * * \\
0.535 * * *\end{array}$ & $\begin{array}{l}-0.279 \text { * } \\
-0.309 \text { * } \\
-0.274 \text { * } \\
-0.303 \text { * }\end{array}$ & $\begin{array}{l}0.597 * * * \\
0.504 * * * \\
0.631 * * * \\
0.532 * * *\end{array}$ & $\begin{array}{l}0.605 * * * \\
0.509 * * * \\
0.674 * * * \\
0.570 * * *\end{array}$ & $\begin{array}{l}0.570 * * * \\
0.465 * * * \\
0.695 * * * \\
0.571 * * *\end{array}$ \\
\hline
\end{tabular}

